\title{
DESCRIPTIONS OF NEW WEST AFRICAN LYCAENIDAE.
}

\author{
BY W. J. IIOLLAND, PITTSBURG, PA.
}

The insects described in the following pages were all taken upon the upper waters of the River Ogove in the French Territory of Gaboon. They were collected by my friend, Rev. A. C. Good, during his stay there, which terminated in the spring of the year 1889 . It is my intention as soon as possible to publish figures of all of these species.

Euliphyra, gen. nov.

\section{E. MIRIFICA, sp. nov.}

Antennae short; palpi minute, compressed; body robust; anterior wings subtriangular, with the costa strongly arched, the apex truncate, beneath which the outer margin is excavated and concave; the inner margin is more or less sinuate. The posterior wings are subovate, strongly produced at the anal angle and scalloped on the lower third of the outer margin. The color of the upper surface of the wings is uniformly a dull black except that upon the inner margin of the primaries, about half-way between the base and the outer angle, there is a large subquadrate spot of pure white. The color of the under side of the primaries is fuscous shading at the apex into a lavender gray. There is a patch of sooty upon the costal margin and the upper part of the cell midway between the base and the apex. The white spot of the upper surface reappears upon the under side. The secondaries are lavender gray shading toward the outer margin into pale fuscous and ornamented by a number of very irregular dark maroon-colored lines and spots, which enclose at the end of the cell : large patch of silvery scales. Expanse of wings, $53 \mathrm{~mm}$.

The specimen was developed from "a very singular chrysalis, short and thick, and unlike anything of the kind I have observed before, which was found upon the under side of a large leaf. It was black in color." (A. C. Good.)

Type $\delta$ in collection of Rev. W. J. Holland.

This insect is closely allied in some respects to Liphyra leucyania, Hew. Neither of them are truly referable to the genus Liphyra and I propose for their reception a new generic name Euliphyra.

\section{Epitola, Westw.}

\section{E. subfulvida, sp. nov.}

Upper side of head, antennae, palpi, and thorax dark brown; abdomen fulvous. Anterior wing strongly arched near the base, abruptly truncate at the apex, and slightly convex at the middle of the external margin; the posterior wing is subovate, with the outer margin evenly rounded; the inner margin is deeply excavated at the anal angle. The color of the anterior wing is deep cadmium yellow, with the costal margin and the outer margin broadly dark brown. A black spot, fusing with the dark brown costal margin, is located at the end of the cell. The posterior wings are of the same color as the anterior, 
but the dark brown border is much wider and the cadmium yellow area is confined to a small space about the region of the cell. The inner margin, forming a groove in which the body is partly enclosed, is light yellow.

The undersurface of both wings is uniformly cadmium yellow. Under surface of the body, legs, and undersurface of the palpi of the same color. Expanse $33 \mathrm{~mm}$.

Type 9 in collection of Rev. W. J. Holland.

It is with the greatest hesitation that I refer this species to the genus Epitola It will with the following species probably constitute a new genus.

\section{E. PURPURAscens, sp. nov.}

The description of the form of the wings of the preceding is also applicable to the present species. The prevalent color of the upper surface of both wings is a purplish gray of a very delicate cast. The cell of the primaries and a streak beyond it just below the costal margin are black. Just beyond the end of the cell the ground color of the wing fades into a pale blue, and the base of the wing is powdered with greenish scales. The outer margin is lightly shaded with brown. The posterior wings are uniformly of the ground color, save at the base, where they are powdered with greenish scales, and on the outer margin, where they are more narrowly brown than the primaries. The underside of both the primaries and the secondaries are lavender gray. Just before the apex of the primaries a narrow band of dark brown scales takes its rise upon the costa and is extended obliquely across the wing and continued upon the secondaries to the anal angle. The whole surface of both wings is further mottled with minute spots of dark brown, which under the microscope are seen to be composed of from three to five dark-colored scales. Expanse of wings $42 \mathrm{~mm}$.
Type $q$ in collection of Rev. W. J. Holland.

\section{E. GOODII, sp. nov.}

Upper surface of both primaries and secondaries morpho-blue. The costa of the primaries from the base and the apical half of the wing are broadly black. The blue cuts into the broad black area of the wing near the end of the cell. The margin of the secondaries is very narrowly black except at the outer angle which is somewhat broadly fuscous.

The under surface of both wings is chalky white, traversed by a number of irregular bands of faint brown. There is a very narrow marginal black line. Expanse of wings $44 \mathrm{~mm}$.

Type $\delta$ in collection of the author.

\section{E. Cercenoides, sp. nov.}

The prevalent color of the upper surface of both wings is a very intense lapis lazuli, showing in certain lights a beautiful greenish iridescence. The costal margin of the primaries is narrowly and the apical third broadly black. At the end of the cell there is a somewhat curved triangular spot of the same color, and the median and submedian nerves are covered with black scales toward the base. The anterior margin of the secondaries is broadly, and the external margin very narrowly black. The fringe of the primaries just before the outer angle, and the fringe of the secondaries just behind the outer angle is narrowly white. The underside of both wings is dark plumbeous, ornamented with numerous transverse bands of waved lines and sagittate spots of a pale blue color, of which those at the outer angle of the primaries are the broadest. Expanse of wings 36 $\mathrm{mm}$.

Type $\delta$ in collection of the author. 


\section{E. Benitensis. sp. nov.}

The costal margin of the primaries of this small and well marked species is very strongly arched and the apex is more acute than in any other species of which the writer has knowledge. The color of the upperside of the anterior wings is black, ornamented with blue spots, of which one, very small, is situated on the middle of the cell, and another of the same size, just beyond the cell; while five are disposed in the form of a transverse submarginal series which is interrupted between the second and third median nervules, and in which the spots increase in size toward the posterior margin. The base of the wing and the costa are powdered with a few scattering blue scales. The posterior wing is morpho-blue with the anterior and outer margins and the median nerve and nervules broadly black. The inner margin is gray. The prevalent color of the under surface of both wings is a dark wood brown. The discal area of the primaries is suffused with blackish. The spots of the upper side reappear upon the under side as very faint bluish gray markings, the edges of which are rather sharper than upon the upper side. There is in addition a faint marginal band of lunules. The secondaries are ornamented with a similar faint marginal and submarginal band of lunules, and with three or four spots about the end of the cell. Head, thorax, and abdomen concolorous. Expanse of wings $30 \mathrm{~mm}$.

Type $\delta$ in collection of the writer.

\section{E. umbratilis, sp. nov.}

Allied to $E$. marginata, Kirby, but differing from this species in being of a paler blue upon the upper surface, and by not having the margin of the wings denticulated and the denticulations dusted with white. Upon the under side there are also marked differences. 'The general ground color is as in Kirby's species, but the irregular zig-zag markings are more numerous and more sharply defined than in E. marginata, and are disposed in well-marked transverse series giving the wing a somewhat banded appearance.

\section{Phytar.a, Westw.}

\section{P. elais, Doub, Hew.Female.}

The female of this interesting species, so far as I am at present aware, has not hitherto been described. I have a specimen taken in coitu with a typical male. It is uniformly brown upon the upper side except upon the apical half of the primaries where the brown shades gradually shade into deep velvety black, which is interrupted beyond the end of the cell by a broad subapical band of yellow which extends from the costa to the third median nervule, and is constricted at the upper radial. The under side is not materially different in markings from the male, except that the yellow band faintly re-appears, and the general tone of the markings is lighter. Expanse of wings, $67 \mathrm{~mm}$. The example was taken upon $5^{\text {th }}$ Jan., I887, at Kangwe.

\section{Pseuderesia, Butl.}

\section{P. o-rubrum sp. nov.}

This species is closely allied to $P$. Catalina, Kirby and Smith, but differs 
in the almost entire absence of any red markings on both sides of the wings. My sole example is a female.

The upper side of the head, body and wings is uniformly dark brown. The under side is also dark brown, becoming paler at the base and the outer margins of both wings, which have a faint submarginal and marginal band of sagittate grayish spots disposed regularly upon the intra-neural spaces. Four vermilion spots are clustered about the end of the cell in the secondaries, and all of these except the one just beyond the end of the cell are pupilled with dark brown, giving them the appearance of the letter "O" in crimson. Expanse of wings $40 \mathrm{~mm}$.

Type in author's collection.

1o. P. latruncularia, sp. nov.

Allied to $P$. helena, Druce, but differing in the following particulars :

ist. The total absence of all crimson markings,

2nd. The spots of the under side, which agree in the main in location with the spots of the under side of $P$. helena, as figured in Kirby \& Smith (except that the red ones are wanting), are not yellow but brilliant white and larger, and more sharply defined. Otherwise the description of $\mathrm{Mr}$. Druce holds good.

This may prove to be a local or seasonal form of $P$. helena.

Type $\delta$ in collection of the author.

\section{P. DespeCta, sp. nov.}

ð. Upper surface uniformly dull purplish black. Under side dull blackish gray, darkest at the base of the primaries. Both the primaries and the secondaries are traversed by marginal, submarginal, and median bands of pale whitish sagittate marks. There are also upon the secondaries a number of obscure little markings in the region of the cell.

o. The female is like the male except that the apex of the primaries is less acute and the outer margin more rounded, and the color of the upper surface is pale reddish brown.

Described from $5 \hat{\delta} \hat{\delta}$ and 2 오 in the author's collection.

\section{SPALGIS, Moore.}

\section{S. S-Signata, sp. nov.}

8. Upperside. Head, thorax, abdomen, and anterior wing upon the base, anterior margin, apex, and outer margin, black. The rest of the upper surface of the wings pure white, except that there is a very fine black marginal line surrounding the secondaries, and that the extremities of the nervules of these wings are marked with black points. Underside. The underside is white shading iuto a very pale gray upon the costal and outer margin of the primaries. This shade is due apparently to the black upon the upper surface. The anterior wing has a triplicate, and the posterior wing a geminate marginal line. These are followed toward the base by series of more or less broken and interrupted lines, more thickly distributed at the base than elsewhere. In the cell there are two annular spots, of which the outermost and largest has the appearance of the letter "S." The ends of the nervures are tipped with black. Expanse $34 \mathrm{~mm}$.

q. The female has the anterior wings with the apex less produced, and the outer margin more rounded. The outer margin of the secondaries is also broadly black like the margin of the anterior wings. The under- 
side is white, all the narrow lines and markings which appear in the case of the male being obsolete except those about the outer margins of the wings. Expanse $30 \mathrm{~mm}$.

Described from examples taken in coitu, and contained in the collection of the author.

It is with much hesitation that I refer this insect to Mr. Moore's genus Spal$g$ is, but it comes nearer to it apparently than to any other of these erected by lepidopterists. It will probably become the representative of a new genus, when the future revision of the lycaenidae takes place.

\section{LACHNOCNEMA, Trim.}

\section{I3. L. exiguus, sp. nov.}

Upperside. Head, thorax, abdomen and antennae black. Wings white with the costal and outer margins of the anteriors and the outer margin of the secondaries broadly black.

Underside. Legs white, and also the abdomen except at the tip where it is fuscous. Wings white with the costa of the primaries narrowly and the apical third broadly washed with pale wood brown. The outer margin of the secondaries is also broadly suffused with the same color. Near the apex of the primaries there is a submarginal row of three and a marginal row of five gilt spots. Near the anal angle of the secondaries there is a similar series of marginal and submarginal spots, and upon the anterior margin of the secondaries there are three elongated coppery gilt spots. Expanse $25 \mathrm{~mm}$.

Type $\delta$ in collection of the author.
LARINOPODA, Butler.

I4. L. PERFRAgilis, sp. nov.

Upper side. Antennae, head, thorax, and abdomen black. Wings pellucid, white. The costal and outer margins of the primaries are somewhat broadly and the outer margin of the secondaries very narrowly laved with black. There is a round black spot at the end of the cell of the secondaries.

Under side. Exactly as the upper. The legs are crimson. Expanse of wings $40 \mathrm{~mm}$.

Type in coll. Holland.

\section{i 5. L. campimus, sp. nov.}

Allied to L. libyssa, Hew., and closely resembling it upon the upper side. The broad black margin of the wings is however quite regular and not excavated on the costa at the end of the cell of the primaries, and just below the outer angle of the secondaries as in $L$. libyssa, and the markings of the under surface being different do not appear the same upon the upper surface which permits of their being seen un account of the partly diaphanous nature of the wings. Underside. Anterior wings white, with the costal and outer margins broadly black, the black being extended downward upon the cell in the form of a couple of teeth. At the apex the black area is interrupted by a lunate white spot and a narrow marginal line. The posterior wings are also white with the outer and inner margins broadly black. Just before the middle of the anterior margin a broad straight band of black arises and crosses the wing diagonally to the inner margin; a similar black band extending from near the outer angle of the wing runs parallel to and at a slight remove from the anterior margin and coalesces with the broad black diagonal band. The broad outer band of black is adorned near the outer angle by a large white spot which is followed toward the anal angle by several smaller spots of the same color. Expanse $28 \mathrm{~mm}$.

Type $\delta$ in collection of the writer. 
D'URBANIA, Trim.

\section{D. MONDo, sp. nov.}

Upperside of head, antennae, and body dark brown. Ground color of both wings orange red. The base and costa of the anterior wing is covered with minute blackish striae and spots. The apex and outer margin are black. There are three black spots in the cell of which the outermost is the largest, and there are three connected and somewhat irregulal spots which form a band running from the middle of the costa toward the outer margin with which they partly fuse. The outer maigin of the secondaries is broadly dark brown, and the surface of the wing is very densely mottled with the little spots and striae described as appearing upon the primaries. This maculation is least dense upon the nervures, and the wing has thus a rayed appearance imparted to it. The underside of the anterior wing is lighter red than the upper; the base, costa, apex, and outer margin are gray irrorrated with minute black dots. The spots reappear as upon the upper surface, and in addition a large spot between the second and third median nervules. The underside of the secondaries is of the same gray color as the base of the primaries. There is a waved marginal line, an interrupted submarginal series of black spots arranged in two groups of three spots each; a transverse series of four spots extending across the wing, the spot nearest the inner margin being the smallest, and three spots at the base. These spots are not quite constant, and there are sometimes one or two more minute ones upon the wing. The female does not differ materially from the male. Expanse of wings $\delta 35 \mathrm{~mm}$., o 32 . $\mathrm{mm}$.

Described from four males and two females in author's collection.
I7. D. oshebA, sp. nov.

Upperside of head and body black. Wings with their outer margins scalloped and the fringes narrowly gray between the extremities of the nerrules. The anterior wing is broadly black, with a minute spot of crimson near the base and a larger spot of the same color on the posterior margin. The hindwing is crimson bordered evenly with black. In some specimens the border is narrower on the inner margin. There are a number of small black spots at the base. The underside of the wings is brown with a plumbeous sheen. There are a few obscure dark marks at the base of both wings. The crimson spot at the posterior margin of the primaries reappears upon the lower side and is surmounted by a small spot of the same color. There are a few crimson spots at the base of the secondaries, and a curved band of crimson spots crosses the middle of the wing, which is darker in the region of this band than elsewhere. The female does not materially differ from the male except as that sex always differs in the genus by having the apex of the primaries less acute. Expanse of wings $27 \mathrm{~mm}$.

Described from two males and two females in author's collection.

\section{I8. D. Ashira, sp. nov.}

Allied to $D$. libentina, Hew. Upper surface of the wings uniformly black except at the anal angle of the secondaries where there is a large subovate crimson spot. The underside is marked very much as in $D$. libentina but the ground color is darker and the crim. son spots smaller and differently shaped. Nothing but a good figure can convey the idea of these differences, and such a figure I hope soon to publish.

Type in collection of the author. 


\section{D. оцомво, sp. nov.}

Ground color of the upper side of the wings tawny red. The costal and outer margin of the primaries broadly black, as also the outer margin of the secondaries. The inner matter of the latter and the base fuscous. The ground color of the underside of the primaries is pale reddish, palest at the posterior margin. The broad black border of the costa is broken near the middle by a line of the ground color which passes upwards to the edge of the costa. This is followed toward the apex by two narrow dashes of ochraceous, two submarginal bands of sagittate spots decreasing in size from the costal margin, and by a narrow marginal line. The ground color of the underside of the secondaries is ochraceous. The black border is interrupted by a narrow marginal line and the double band of sagittate spots like that on the primaries. Beyond this toward the base are from twelve to fourteen spots of black of which the one at the middle of the anterior margin which is subquadrate in form is the largest. The male and female are not unlike. Expanse of wings 35 to $39 \mathrm{~mm}$.

Described from five examples in collection of the author.

\section{TERIOMIMA, Kirby.}

\section{T. ineucostola, sp. nov.}

Allied to T. tenera, Kirby. The wings are white. The costal margin of the primaries is very narrowly and the apical third very broadly blackish gray, with the dark margin, however, terminating abruptly before reaching the inner angle. There is no black border upon the secondaries. The underside is uniformly creamy white, with a faint trace of a black marginal line near the apex of the primaries. Fringe very narrowly black check- ered with white. Legs black. Expanse of wings $28 \mathrm{~mm}$.

Described from four examples in collection of the author.

2I. T. Xanthostola, sp. nov.

Allied to the preceding species. The ground color of the wings is pale luteous. The costa and the apical third are bordered with black as in the preceding species, but the inner margin of the black border is more evenly rounded than in $T$. leucostola, and reaches to the outer angle of the wing. The anal angle of the secondaries is slightly margined with grayish. Underneath there are no dark markings except faint traces of a marginal line here and there. The fringe is exceedingly narrow and dark brown checkered with pale gray. Legs dark brown. Expanse of wings $26 \mathrm{~mm}$.

Described from numerous examples in the collection of the author.

\section{T. Xanthis, sp. nov.}

Allied to Pentila (?) evanescens, Kirby. It differs in being smaller, darker yellow, without any blackish border on the primaries except at the tip, and no trace whatever of such a border upon the secondaries. The underside is immaculate and the only ornamentation consists of a faint submarginal band near the apex of the primaries, and three faint lines traversing the posterior wings parallel to the outer border upon the outer third. Expanse $27 \mathrm{~mm}$.

Described from numerous examples in the collection of the author.

\section{APHNAEUS, Hübn.}

23. A. Ilogo sp. nov.

Allied to $A$. orcas, Drury. Upperside. 
Front and a narrow line around the eyes white Antennae, head, thorax, and abdomen black. Primaries black, with the lower third of the wing almost to the outer margin densely covered with blue scales. There are besides three small blue spots on the cell near the base, and two at the end of the cell pupilled with white. Beyond these a few scattering blue scales. Secondaries black laved with blue upon the discal area. There are two small white spots at the point where the longest of the two tails joins the outer margin, and at the indentation of the inner margin just above the anal lobe there is a white spot. Underside. The ground color is deep cadmium orange. The fringes are black. The wings are ornamented with silvered spots bordered with black, and disposed as follows:-- Upon the anterior wing, a round spot upon the cell near the base, followed by a figure 8 spot on the middle and a long spot at the end of the cell; beyond this near the costa three small spots closely clustered, below these a larger oval spot, and between the median nervules at their origin two small spots the border of the lower one of which fuses with the border surrounding the very large spot which covers almost the entire inner margin of the wing: there are six small submarginal spots, three near the apex, and three near the inner angle of the wing;-upon the posterior wing a small spot upon the costa at the base, a round spot in the cell and two oval spots which coalesce at the end and a small oval spot below the cell, beyond these a curved series of six spots, of which the third is very small and the last geminate situated below the first median nervule; upon the inner margin about the middle is a round spot succeeded by an oblique bar having at its outer extremity a small spot, this is succeeded by another shorter bar, at the end of which is a short curved series of three small spots. Just above the anal lobe there is a small triangular mark. The anal lobe is black, ornamented with two silvery blue spots. Tails black narrowly tipped with white. Underside of the palpi orange, legs and abdomen black ringed with white. Expanse of wings $36 \mathrm{~mm}$.

\section{Type $\delta$ in author's collection.}

\section{A. ARGENTEOLA sp. nov.}

Allied to the preceding species. Upperside:-Antennae, head, thorax, and abdomen black. Wings brilliant greenish blue, with the costa and apical third of the primaries and costal and inner margins of the secondaries broadly black. Anal lobe black minutely spotted and margined with white. Tails black tipped with white. Underside:Ground color rich maroon, shading upon the inner margin of the primaries into fuscous. The spots are located as in the preceding species but with certain marked differences. Ist, They are all smaller, more sharply defined, and less disposed to fuse. 2ndly, Upon the anterior wing the three clustered spots are succeeded by a long silvery bar extending outwardly toward the margin, instead of by an oval spot. 3 rdly, 'The spots of the secondaries are more $n$ umerous and their disposition is slightly different. $4^{\text {thly, }}$, The submarginal series of spots on both wings is composed of almost obsolete grayish points without any apparent trace of silvery pupillation in the specimens I have seen. Expanse of wings $23 \mathrm{~mm}$.

\section{Type $\delta$ in author's collection.}

\section{A. CRUSTARIA, sp. nov.}

Upperside :-Head and body black. Wings morpho-blue, the costa and apical third of the primaries and anal lobe of the secondaries black. Underside :-The ground color of the wings is pale stramineous. The fringes are very narrowly black checked with the ground color. There is a double marginal line of fuscous upon both wings. The spots are silvery copper bordered with reddish gray. Upon the primaries these spots are arranged 
as transverse bars at right angles to the costal margin. Near the base of this wing below the cell there is a dark fuliginous mark. The spots upon the secondaries are crowded together toward the base and again toward the outer margin, leaving a clear discal band of the ground color visible. Three small round spots near the base and a quadrate bar in the outer series are conspicuous because showing no silvery pupillation and being darker in color than the rest. Anal lobe black. Palpi, legs and body concolorous. Expanse $27 \mathrm{~mm}$.

Type $\delta$ in collection of the author.

\section{A. Argyrocyclus, sp. nov.}

q. Allied to $A$. orcas, Drury, but differing widely in important particulars from the female of that species.

Upperside:-The prevalent color is dark greenish brown glossing with blue in certain lights. There is a large white spot at the end of the cell of the primaries followed by a subapical series of very small and obscure spots. Underside:-The ground color is dark orange fading upon the inner margin of the primaries into pale testaceous. The fringes are black checked with white at the tips of the nervures. The anal lobe is black. The silvery spots adorning the wings are relatively large and ringed with dark maroon. Instead of the one long spot which stands upon the primaries of $A$. orcas the fourth from the base, there are in $A$. argyrocyclus three spots grouped triangularly. Instead of the nine silver spots which appear upon the secondaries of $A$. orcas there are in $A$. argyrocyclus sixteen spots and all lying within the submarginal band of dark maroon which in both species appears upon the secondaries. Expanse of wings $40 \mathrm{~mm}$.

Type in collection of author. Pittsburg, Pa., Io Nov. I8go.

\section{SOME GENERA OF OEDIPODIDAE RESCUED FROM THE TRYXALIDAE.}

BY SAMUEL HUBBARD SCUDDER, CAMBRIDGE, MASS.

In his Prodromus Oedipodiorum, Saussure constructs a table for the separation of the genera of this family, in which, when he has reached the "stirps Oedipoda," afterwards termed by him Oedipodites, he first separates from the remainder of the stirps the new genus Daemonea, an extraordinary form from Peru, known to him apparently only by a single imperfect and immature specimen in Brunner's collection. This genus he found to differ from all others in the forward extension of the vertex, "faciem adumbrans," the stout form of the hind femora with slight carinae, the great length of the hind tarsi which are nearly two thirds as long as the hind tibiae, and the peculiar concave structure of the dorsal surface of the pronotum.

In a recent study of some American species of acridiodea I have been greatly puzzled by a number of forms which seemed to lie on the border land between the oedipodidae and the tryxalidae. One by one they have been removed in my collection from one family and the other without finding a 

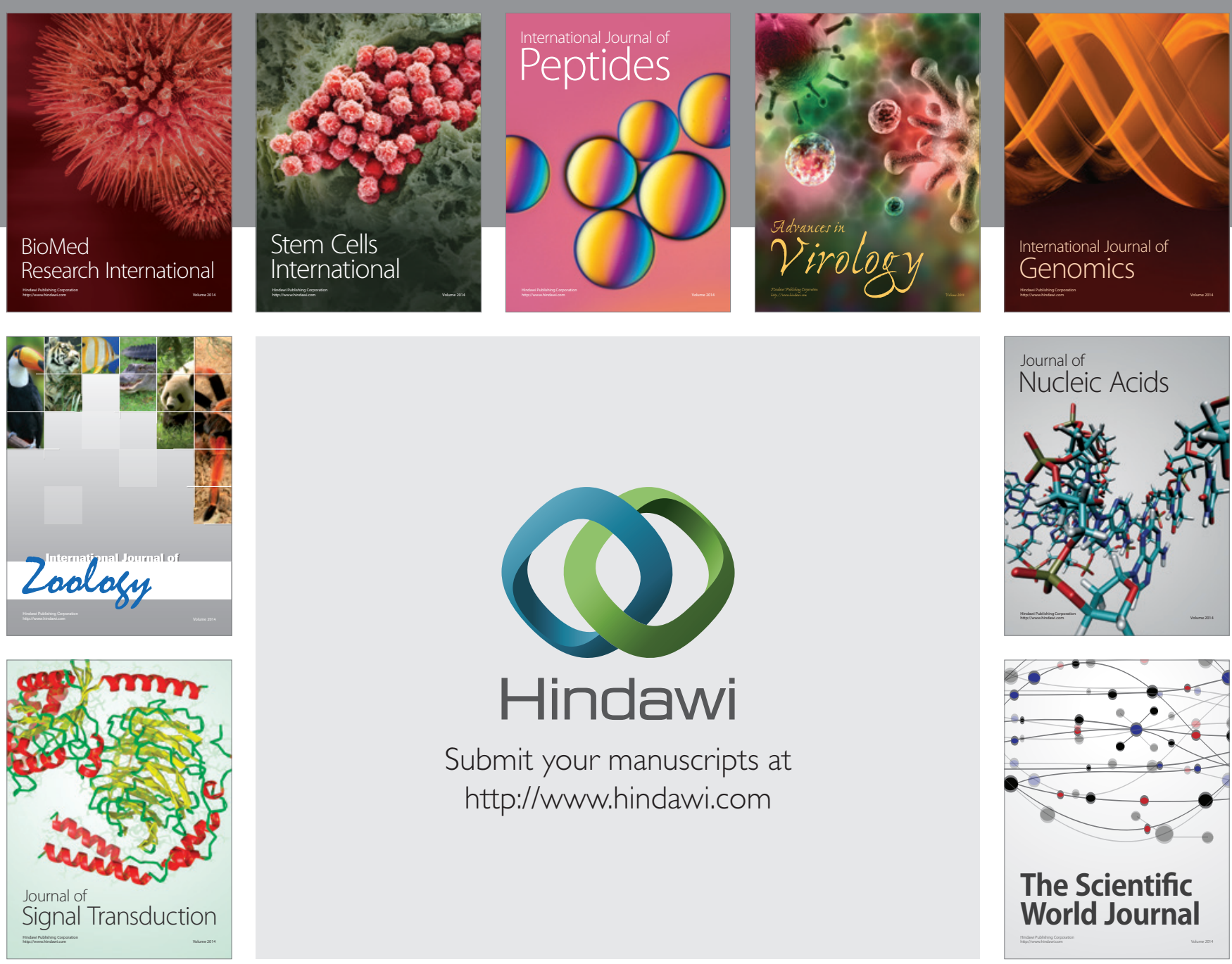

Submit your manuscripts at

http://www.hindawi.com
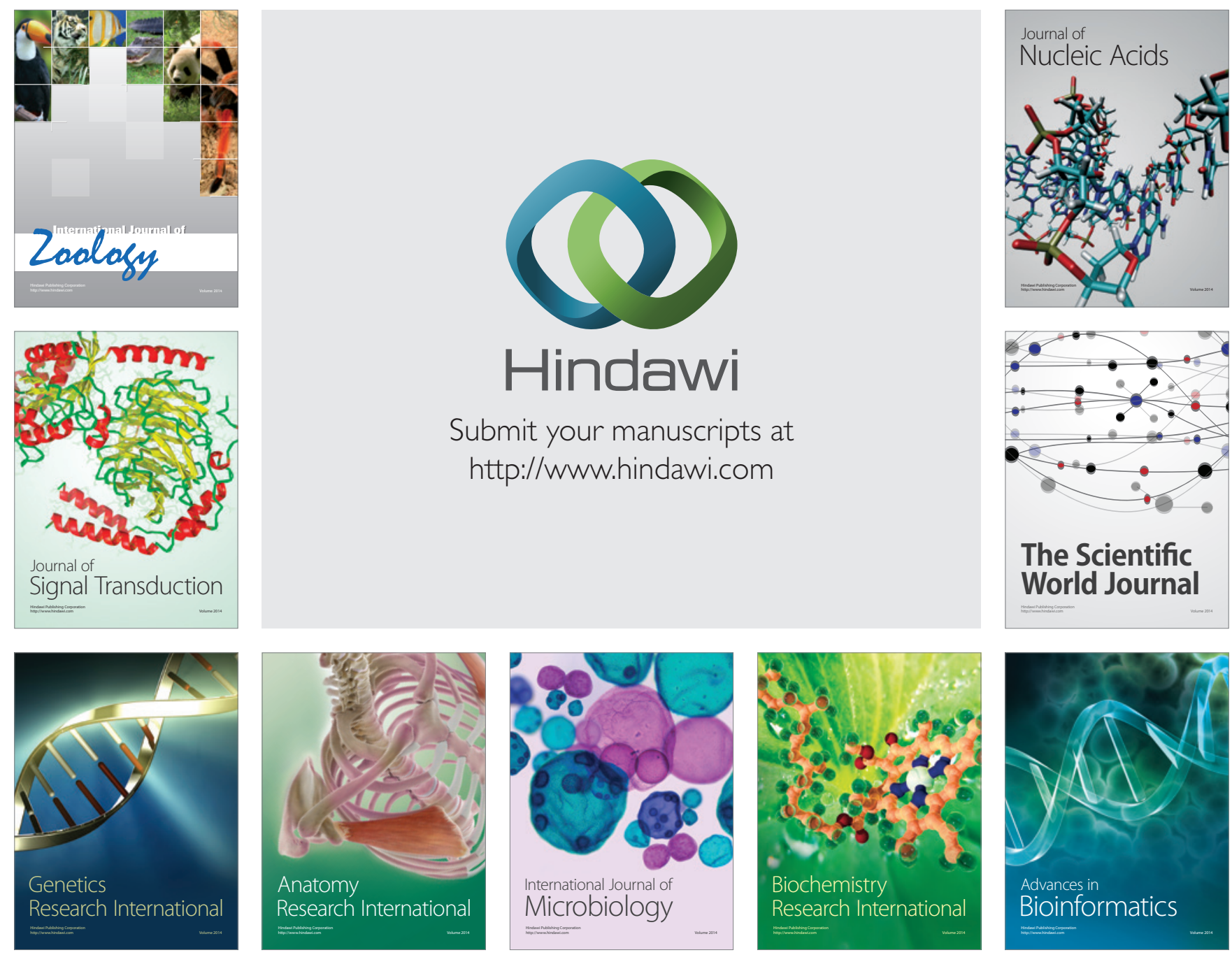

The Scientific World Journal
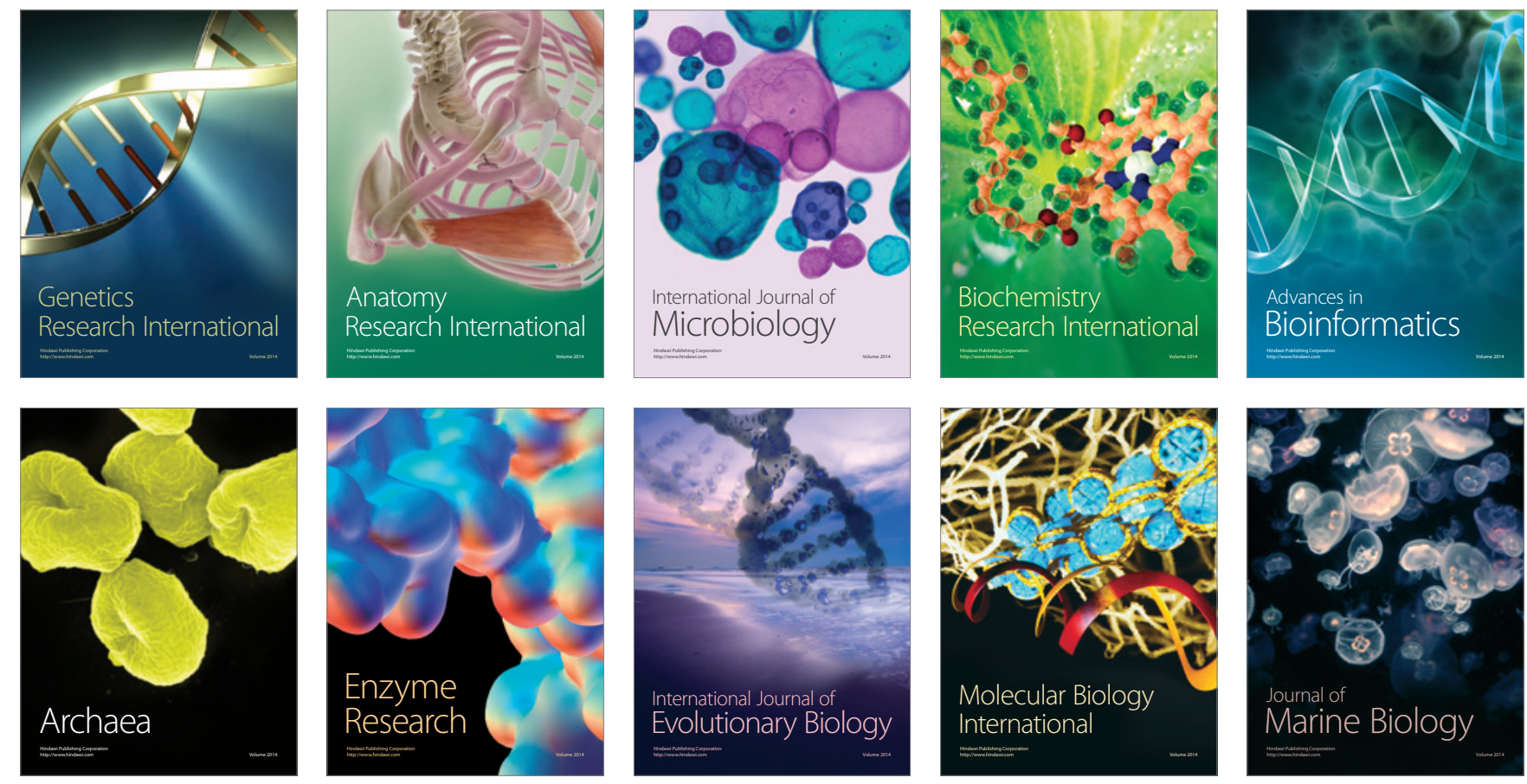